\title{
Planning of design works and formation of the initial permissive documentation for projects of general education institutions
}

\author{
Pavel Oleinik, Alexey Yurgaytis*, and Aleksandra Popova*. \\ Moscow State University of Civil Engineering, Yaroslavskoe shosse, 26, Moscow, 129337, Russia
}

\begin{abstract}
In this article, the stages of erecting the building of a general education institution (GEI) from the moment of the formation of the idea of construction to the transfer of the object into operation are considered. Based on the personal experience of the authors, as well as the study of the corresponding regulations for obtaining the initial permissive documentation (IPD), a list of IPDs was formed. In addition, during the study, a conditional schedule was drawn up for the collection of the IPD, as well as the necessary approvals for the initial phase of the object design.
\end{abstract}

\section{Introduction}

Nowadays in the Russian Federation because of large-scale programs the development of education in the country's regions raises the need for designing, building new buildings, and also for reconstructing operated general educational institutions, pre-school educational organizations and universities. The main stages of the investment and construction project are presented in Table 1.

Table 1. The main stages of the investment and construction project

\begin{tabular}{|c|c|c|c|}
\hline No. & Stage & Participants of the stage & Necessary result \\
\hline 1 & Forming an idea & $\begin{array}{l}\text { An investor (investor) is a le- } \\
\text { gal or natural person who makes long- } \\
\text { term investments. }\end{array}$ & $\begin{array}{l}\text { Idea for further detailed } \\
\text { development }\end{array}$ \\
\hline 2 & Feasibility study & $\begin{array}{l}\text { Investor; } \\
\text { The developer is a legal entity } \\
\text { or an individual owning (on the right of } \\
\text { ownership, on the basis of a gratuitous } \\
\text { use agreement, etc.) a land plot on } \\
\text { which the construction of an object of } \\
\text { capital construction is proposed; } \\
\text { The customer is a legal entity } \\
\text { or an individual contracting a state } \\
\text { contract for the construction of a prop- }\end{array}$ & $\begin{array}{l}\text { Feasibility study (Decision } \\
\text { making and obtaining the } \\
\text { necessary approvals with } \\
\text { the administration of the } \\
\text { locality on the need to lo- } \\
\text { cate the object) }\end{array}$ \\
\hline
\end{tabular}

\footnotetext{
* Corresponding author: aljurgaitis@gmail.com

* Corresponding author: sasha397151948@gmail.com
} 


\begin{tabular}{|c|c|c|c|}
\hline No. & Stage & Participants of the stage & Necessary result \\
\hline & & $\begin{array}{l}\text { erty. } \\
\text { The investor, the developer } \\
\text { and the customer can be in one person. }\end{array}$ & \\
\hline 3 & $\begin{array}{l}\text { Organization and } \\
\text { conduct of an open } \\
\text { tender for the exe- } \\
\text { cution of design } \\
\text { work }\end{array}$ & $\begin{array}{l}\text { The customer; } \\
\text { Designer - a legal entity or an } \\
\text { individual who develops, on request and } \\
\text { contract with the customer, project and } \\
\text { estimate documentation for new con- } \\
\text { struction, reconstruction. }\end{array}$ & $\begin{array}{l}\text { Determination based on the } \\
\text { results of an open tender for } \\
\text { a general designer, conclu- } \\
\text { sion of a contract. }\end{array}$ \\
\hline 4 & Designing an object & Designer & $\begin{array}{l}\text { Performing works for the } \\
\text { development of project } \\
\text { documentation, incl. obtain- } \\
\text { ing the necessary initial } \\
\text { permissive documentation } \\
\text { (IPD), design and estimate } \\
\text { documentation for the facil- } \\
\text { ity }\end{array}$ \\
\hline 5 & $\begin{array}{l}\text { Coordination of the } \\
\text { project with the } \\
\text { customer }\end{array}$ & $\begin{array}{l}\text { Customer; } \\
\text { Technical customer } \\
\text { Designer }\end{array}$ & $\begin{array}{l}\text { Coordination of design, } \\
\text { design and estimate docu- } \\
\text { mentation with the custom- } \\
\text { er and technical customer. }\end{array}$ \\
\hline 6 & $\begin{array}{l}\text { Passage of the state } \\
\text { expertise }\end{array}$ & $\begin{array}{l}\text { Designer; } \\
\text { State Expertise - the activities } \\
\text { of expert bodies, the main purpose of } \\
\text { which is to identify the extent to which } \\
\text { the objects of expertise meet the estab- } \\
\text { lished standards, standards and rules in } \\
\text { the field of capital construction objects. }\end{array}$ & $\begin{array}{l}\text { Getting a positive conclu- } \\
\text { sion after removing com- } \\
\text { ments from the state expert } \\
\text { review for compliance with } \\
\text { project documentation with } \\
\text { the requirements of estab- } \\
\text { lished norms, standards and } \\
\text { rules. } \\
\text { Transfer of a copy of pro- } \\
\text { ject documentation, positive } \\
\text { conclusion to the customer. }\end{array}$ \\
\hline 7 & $\begin{array}{l}\text { Organization and } \\
\text { conduct of an open } \\
\text { tender for construc- } \\
\text { tion works for the } \\
\text { facility }\end{array}$ & $\begin{array}{l}\text { Customer; } \\
\text { The general contractor is a le- } \\
\text { gal entity or an individual who per- } \\
\text { forms a complex of works on the con- } \\
\text { struction of objects for various purpos- } \\
\text { es. }\end{array}$ & $\begin{array}{l}\text { Determination based on the } \\
\text { results of an open tender of } \\
\text { a general contractor, con- } \\
\text { clusion of a contract. }\end{array}$ \\
\hline 8 & $\begin{array}{l}\text { Implementation of } \\
\text { the project for the } \\
\text { production of works }\end{array}$ & The general contractor & $\begin{array}{l}\text { The project for the produc- } \\
\text { tion of works }\end{array}$ \\
\hline 9 & $\begin{array}{l}\text { Performance of } \\
\text { works on the con- } \\
\text { struction of the } \\
\text { object }\end{array}$ & $\begin{array}{l}\text { General contractor; } \\
\text { The subcontractor is a legal } \\
\text { entity or an individual involved in the } \\
\text { performance of certain types of work } \\
\text { under a subcontract agreement with a } \\
\text { general contractor; } \\
\text { The organization that carries } \\
\text { out technical supervision - an organiza- } \\
\text { tion carrying out a complex of verifica- } \\
\text { tion works by experienced experts, in } \\
\text { order to ensure the implementation of } \\
\text { the project in the proper quality, within } \\
\text { a specified time frame, with the estab- } \\
\text { lished cost and volume of materials; } \\
\text { The designer - carries out the }\end{array}$ & Erection of an object \\
\hline
\end{tabular}




\begin{tabular}{|l|l|l|l|}
\hline No. & Stage & Participants of the stage & Necessary result \\
\hline 10 & $\begin{array}{l}\text { Putting the object } \\
\text { into operation }\end{array}$ & $\begin{array}{l}\text { Cuthor's supervision. } \\
\text { General contractor; } \\
\text { Operating organization - a le- }\end{array}$ & $\begin{array}{l}\text { Safe and reliable operation } \\
\text { of the capital construction } \\
\text { site. }\end{array}$ \\
$\begin{array}{l}\text { gal entity or an individual exercising on } \\
\text { the rights of the owner or on behalf of } \\
\text { the owner (most often an investor) of } \\
\text { the technical operation of the facility. } \\
\text { The operating organization is consid- } \\
\text { ered to represent the interests of users, } \\
\text { unless otherwise stipulated by agree- } \\
\text { ments between the participants of the } \\
\text { investment process. }\end{array}$ & \\
\hline
\end{tabular}

In this article, the 4th stage of the investment and construction project - design is considered in more detail.

\section{Designing an object}

\subsection{Requirements for the objects of GEI}

A diagram was drawn up to determine the functional purpose of the GEI.

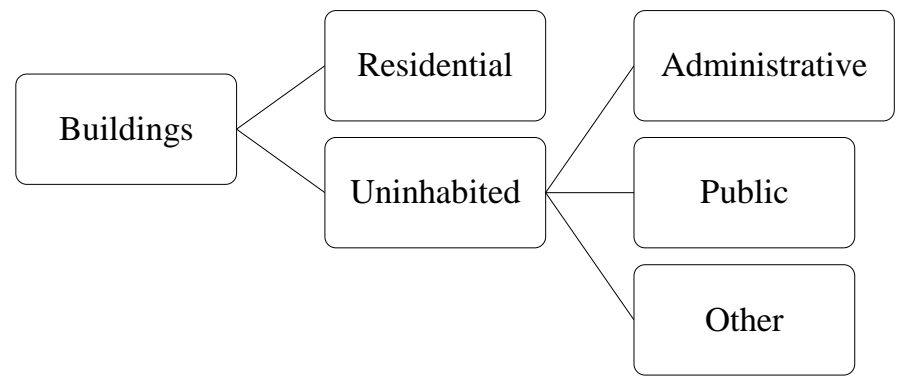

Fig. 1. Diagram of the functional purposes of buildings.

General educational organizations ensure the implementation of general education activities in accordance with the levels of education defined by federal law [1]: (Federal Law of December 29, 2012 No. 273-FZ "On Education in the Russian Federation" (edited on June 2, 2016).

- primary general education (grades 1-4);

- basic general education (grades 5-9);

- Secondary general education (10-11 or 8, 9-11 grades).

Table 2. The list of basic norms, standards and rules that are used in the design of general education institutions.

\begin{tabular}{|c|c|c|}
\hline No. & \multicolumn{1}{|c|}{ Requirements for designing } & $\begin{array}{c}\text { Character of the } \\
\text { norm }\end{array}$ \\
\hline 1 & $\begin{array}{l}\text { SP 251.1325800.2016 [2] } \\
\text { This set of rules establishes in the territory of the Russian Federation } \\
\text { the requirements for the location and organization of a network of } \\
\text { buildings and complexes of general education organizations, to the site } \\
\text { of the territory, functional groups, composition and areas of premises, }\end{array}$ & Recommendatory \\
\hline
\end{tabular}




\begin{tabular}{|c|c|c|}
\hline No. & Requirements for designing & $\begin{array}{c}\text { Character of the } \\
\text { norm }\end{array}$ \\
\hline & volume planning decisions, lighting, engineering equipment. & $\begin{array}{c}\text { Mandatory } \\
\text { (according to [4]) }\end{array}$ \\
\hline 2 & SP 63.13330.2012 [3] & $\begin{array}{c}\text { Mandatory } \\
\text { (according to [4]) }\end{array}$ \\
\hline 3 & SP 118.13330.2012 [5] & $\begin{array}{c}\text { Mandatory } \\
\text { (according to 1.4. } \\
\text { [6]) }\end{array}$ \\
\hline 5 & $\begin{array}{c}\text { Sanitary-epidemiological rules and standards SanPiN 2.2.1/2.1.1.1278- } \\
03 \text { [7] }\end{array}$ & $\begin{array}{c}\text { Mandatory } \\
\text { (according to 1.4. } \\
\text { [7]) }\end{array}$ \\
\hline
\end{tabular}

\subsection{Composition, procedure and sequence of necessary approvals and IPDs}

The general designer is determined by the results of an open tender, information about which can be found on the official website of the "Unified information system in the procurement sphere" (http://zakupki.gov.ru/epz/main/public/home.html). After selecting the contest of interest, the applicant organization should study the attached tender documentation, familiarize itself with the evaluation criteria, as well as with the scoring system according to the criteria. The results of the check by the competitive commission of the packages with the tender documentation of all the contest participants are published on the site. Organization-winner of the competition for design and survey works concludes the contract with the customer and begins to fulfill its conditions. A mandatory annex to the contract is the technical design assignment (TDA), which sets out the main requirements for the projected capital construction site.

The next stage is the execution of a draft project (DP), which includes: a plan for the planning of the site, architectural and technological solutions for the projected facility, facades of the building with an estimated collation, and visualization of the idea in the form of a 3D model. In addition to DP, it is necessary to prepare a material card (MC), which indicates: the material of load-bearing structures, type of foundation, enclosing structures, facade system, etc. The draft project and the material card must be agreed with the Customer, the Ministry of Education and the Administration of the settlement, in which the construction is planned. If necessary, adjustments are made to the DP and MC, after which a reconciliation procedure is repeated.

After obtaining the necessary approvals, the designer can proceed to the main stage design. At this stage, it is required to assemble the necessary package of initial permissive documentation (IPD) to provide the departments of the project organization with the necessary initial design data.

In the process of studying the topic, as well as on the basis of personal experience, an auxiliary table was compiled containing a list of the necessary IPDs to be obtained in the process / before the start of the design (Table 3). Also, the table contains excerpts from the regulations of organizations in which it is necessary to obtain the IPD. 
Table 3. The list of the necessary IPDs to be obtained in the process/before the start of the design.

\begin{tabular}{|c|c|c|c|c|c|}
\hline No. & $\begin{array}{l}\text { Name of the } \\
\text { document }\end{array}$ & Responsible & $\begin{array}{l}\text { Organization, pre- } \\
\text { delivering the IPD }\end{array}$ & $\begin{array}{l}\text { Deadline for the } \\
\text { document / labor } \\
\text { for execution, } \\
\text { days }\end{array}$ & $\begin{array}{l}\text { Annex to the } \\
\text { request / ap- } \\
\text { plication }\end{array}$ \\
\hline 1 & Draft project & $\begin{array}{l}\text { Architect; } \\
\text { Technologist }\end{array}$ & $\begin{array}{l}\text { reconciliation with } \\
\text { the administration } \\
\text { of the settlement, } \\
\text { the Ministry of } \\
\text { Education and } \\
\text { Science of the } \\
\text { Russian Federa- } \\
\text { tion, the customer }\end{array}$ & $\begin{array}{c}5 \\
\text { (implementation) } \\
+1 \text { (agreement) }\end{array}$ & \\
\hline 2 & $\begin{array}{l}\text { Town-planning } \\
\text { plan of the stead } \\
\text { (TPPS) }\end{array}$ & $\begin{array}{l}\text { Assistant of } \\
\text { Chief Project } \\
\text { Engineer } \\
\text { (CPE) }\end{array}$ & Customer & Up to 30 days & \\
\hline 3 & $\begin{array}{l}\text { Title documents for } \\
\text { the land area }\end{array}$ & CPE assistant & Customer & Up to 30 days & \\
\hline 4 & $\begin{array}{l}\text { The act of assessing } \\
\text { green plantations in } \\
\text { the project site }\end{array}$ & CPE assistant & $\begin{array}{l}\text { District admin- } \\
\text { istration }\end{array}$ & Up to 30 days & $\begin{array}{l}\text { - Topographic } \\
\text { survey with } \\
\text { the boundaries } \\
\text { of the future } \\
\text { site } \\
\text { - Title docu- } \\
\text { ments for land }\end{array}$ \\
\hline 5 & $\begin{array}{l}\text { Specification for } \\
\text { the connection of } \\
\text { the facility to the } \\
\text { networks of cold } \\
\text { water supply. }\end{array}$ & \multirow{4}{*}{ CPE assistant } & \multirow{4}{*}{$\begin{array}{c}\text { Resource- } \\
\text { supplying organi- } \\
\text { zation } \\
\text { (ex.: "NOVO- } \\
\text { GOR-Prikamye") }\end{array}$} & \multirow{4}{*}{ Up to 30 days } & \multirow{2}{*}{$\begin{array}{l}\text { - Set applica- } \\
\text { tion form } \\
\text { - Foundation } \\
\text { documents of } \\
\text { the customer } \\
\text { - Title docu- } \\
\text { ments for land } \\
\text { - Calculation } \\
\text { of the flow of } \\
\text { water } \\
\text { - TPPS }\end{array}$} \\
\hline 6 & $\begin{array}{l}\text { Specification for } \\
\text { connection to } \\
\text { drainage networks }\end{array}$ & & & & \\
\hline 7 & $\begin{array}{l}\text { Location of fire } \\
\text { hydrants in the area } \\
\text { of design }\end{array}$ & & & & $\begin{array}{l}\text { - Situation } \\
\text { plan with the } \\
\text { plot of the } \\
\text { design }\end{array}$ \\
\hline 8 & $\begin{array}{l}\text { Information on the } \\
\text { project of the sani- } \\
\text { tation zones of } \\
\text { water well bore- } \\
\text { holes }\end{array}$ & & & & $\begin{array}{l}\text { - Situation } \\
\text { plan with the } \\
\text { plot of the } \\
\text { design }\end{array}$ \\
\hline 9 & $\begin{array}{l}\text { Conditions for } \\
\text { connection to pow- } \\
\text { er supply networks }\end{array}$ & CPE assistant & $\begin{array}{l}\text { Resource- } \\
\text { supplying organi- } \\
\text { zation (note: } \\
\text { MRSK of Urals) }\end{array}$ & Up to 30 days & $\begin{array}{l}\text { - Set applica- } \\
\text { tion form } \\
-\quad \text { Foundation } \\
\text { documents of } \\
\text { the customer } \\
- \text { Title docu- } \\
\text { ments for land } \\
-\quad \text { Calculation }\end{array}$ \\
\hline
\end{tabular}




\begin{tabular}{|c|c|c|c|c|c|}
\hline No. & $\begin{array}{l}\text { Name of the } \\
\text { document }\end{array}$ & Responsible & $\begin{array}{l}\text { Organization, pre- } \\
\text { delivering the IPD }\end{array}$ & $\begin{array}{c}\text { Deadline for the } \\
\text { document / labor } \\
\text { for execution, } \\
\text { days }\end{array}$ & $\begin{array}{l}\text { Annex to the } \\
\text { request / ap- } \\
\text { plication }\end{array}$ \\
\hline & & & & & $\begin{array}{l}\text { of the flow of } \\
\text { electricity } \\
\text { - TPPS }\end{array}$ \\
\hline 10 & $\begin{array}{l}\text { Conditions for } \\
\text { connection to heat } \\
\text { supply networks }\end{array}$ & CPE assistant & $\begin{array}{c}\text { Resource- } \\
\text { supplying organi- } \\
\text { zation (note "PAO } \\
\text { T-Plus") }\end{array}$ & Up to 30 days & $\begin{array}{l}\text { - Set applica- } \\
\text { tion form } \\
\text { - Foundation } \\
\text { documents of } \\
\text { the customer } \\
\text { - Title docu- } \\
\text { ments for land } \\
-\quad \text { Calculation } \\
\text { of the flow of } \\
\text { heat } \\
\text { - TPPS }\end{array}$ \\
\hline 11 & $\begin{array}{l}\text { Conditions for the } \\
\text { accomplishment of } \\
\text { the land plot }\end{array}$ & \multirow{3}{*}{ CPE assistant } & \multirow{3}{*}{$\begin{array}{l}\text { Office of the ex- } \\
\text { ternal well-being } \\
\text { of the administra- } \\
\text { tion of the settle- } \\
\text { ment }\end{array}$} & Up to 30 days & \multirow{3}{*}{$\begin{array}{l}\text { - Situation } \\
\text { plan with the } \\
\text { plot of the } \\
\text { design }\end{array}$} \\
\hline 12 & $\begin{array}{l}\text { Specification for } \\
\text { stormwater } \\
\text { drainage }\end{array}$ & & & Up to 30 days & \\
\hline 13 & $\begin{array}{l}\text { Specification for } \\
\text { the accession of } \\
\text { projected drive- } \\
\text { ways to existing } \\
\text { ones }\end{array}$ & & & Up to 30 days & \\
\hline 14 & $\begin{array}{l}\text { Information on the } \\
\text { presence of cultural } \\
\text { monuments and } \\
\text { historical heritage } \\
\text { in the vicinity of } \\
\text { the project site }\end{array}$ & CPE assistant & $\begin{array}{l}\text { State Inspectorate } \\
\text { for the Protection } \\
\text { of Cultural Herit- } \\
\text { age Monuments }\end{array}$ & Up to 30 days & $\begin{array}{l}\text { - Situation } \\
\text { plan with the } \\
\text { plot of the } \\
\text { design }\end{array}$ \\
\hline 15 & $\begin{array}{l}\text { Information on the } \\
\text { lack of (presence) } \\
\text { of cattle and an- } \\
\text { thrax graves }\end{array}$ & CPE assistant & $\begin{array}{l}\text { State veterinary } \\
\text { inspection of the } \\
\text { settlement }\end{array}$ & Up to 30 days & $\begin{array}{l}- \\
\text { plan Situation } \\
\text { application of } \\
\text { the site of } \\
\text { design }\end{array}$ \\
\hline 16 & $\begin{array}{l}\text { Conditions on the } \\
\text { network of outdoor } \\
\text { lighting }\end{array}$ & CPE assistant & $\begin{array}{c}\text { Resource- } \\
\text { supplying organi- } \\
\text { zation (note MUP } \\
\text { NO "Gorsvet") }\end{array}$ & Up to 30 days & $\begin{array}{l}\text { Set applica- } \\
\text { tion form } \\
\text { - Foundation } \\
\text { documents of } \\
\text { the customer } \\
\text { - Title docu- } \\
\text { ments for land } \\
\text { - TPPS }\end{array}$ \\
\hline
\end{tabular}

\subsection{Schedule of works for the organization of design}

Based on the obtained structuring of data from the regulations of organizations providing IPD, and also on the basis of studies of optimization of production activities and scheduling described in earlier publications [8-13], a conditional schedule for the implementation of 
the formation of IPD was drawn up. (Table 4 uses numeric values in the column for document names from Table 3)

Table 4. Conditional timetable for the implementation of the formation of the IPD.

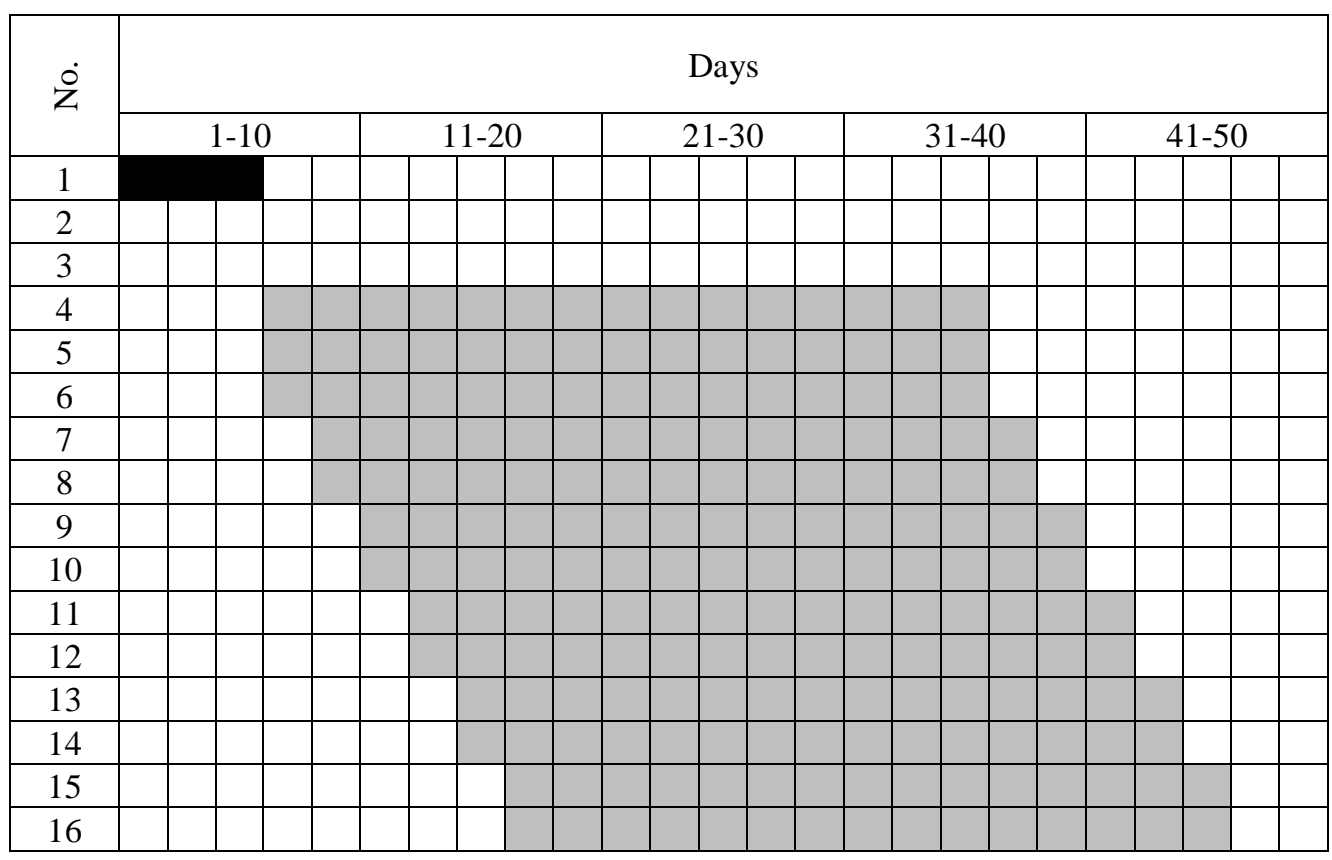

\section{Conclusion}

Knowing what information is necessary for the design, as well as the timing of its provision, it becomes possible to form a conditional timetable for the implementation of work on the formation of IPD. Using this schedule, the project organization can clearly see what time it takes to get all the necessary IPDs. Thus, in order to reduce the time of production, it is allowed to increase the number of specialists to meet the design deadlines. In addition, such routine planning of design works will allow for the technical standardization of the activities of the technical customer, construction control specialists, chief project engineers and coordination departments.

\section{References}

1. Government of the Russian Federation. Federal Law No. 273-FZ "On Education in the Russian Federation" (2012, edited in 2016)

2. Government of the Russian Federation. Svod Pravil 251.1325800.2016 "Zdaniya obsheobrazovatelnych organizacii. Pravila proectirovaniya" [Set of Rules 251.1325800.2016 "Educational institution buildings. Design rules"] (2016)

3. Government of the Russian Federation. Svod Pravil 63.13330.2012 "Betonnye i zhelezobetonnye konstrukzii. Osnovnye polozheniya" [Set of Rules 63.13330.2012 "Concrete and won concrete construction. Design requirements"] (2012)

4. Government of the Russian Federation. Decree No.1521 (26 Dec. 2014) 
5. Government of the Russian Federation. Svod Pravil 118.13330.2012 "Obschestvennye zdaniya i sooruzheniya" [Set of Rules 118.13330.2012 "Public buildings and works"] (2012)

6. Approved by the Chief State Sanitary Doctor of the Russian Federation. Sanitarnye pravila i normy 2.4.2.2821-10 "Sanitarno-epidemiologicheskie trebovanya k usloviam i organizacii obucheniya v obsheobrazovatelnych uchrezhdeniyach" [Sanitary rules and norms 2.4.2.2821-10 "Sanitary and epidemiological requirements for the conditions and organization of education in general education institutions"] (2010, edited in 2015)

7. Approved by the Chief State Sanitary Doctor of the Russian Federation. Sanitarnye pravila i normy 2.2.1/2.1.1.1278-03 "Sanitarno-epidemiologicheskie trebovanya $\mathrm{k}$ usloviam i organizacii obucheniya v obsheobrazovatelnych uchrezhdeniyach" [Sanitary rules and norms 2.2.1/2.1.1.1278-03 "Sanitary and epidemiological requirements for the conditions and organization of education in general education institutions"] (2010, edited in 2015)

8. Oleinik P. Yurgaytis A. Optimization of the annual construction program solutions. MATEC Web of Conferences. - 2017. - Volume 117. - Article Number 00130. RSP 2017 - XXVI R-S-P Seminar 2017 Theoretical Foundation of Civil Engineering https://doi.org/10.1051/matecconf/201711700130 (2017)

9. Topchiy D.V., Scacalov V.A., Yurgaytis A. Comprehensive verification construction compliance control as the Developer's project risk reduction tool. International Journal of Civil Engineering and Technology (IJCIET) Volume 9, Issue 1, January 2018, pp. 985-993

http://http://www.iaeme.com/ijciet/issues.asp?JType=IJCIET\&VType=9\&IType=1 (2018)

10. Dmitriy Topchiy, Anastasia Shatrova and Alexey Yurgaytis. Integrated construction supervision as a tool to reduce the developer's risks when implementing new and redevelopment projects. MATEC Web of Conferences 193, 05032 (2018), ESCI 2018, https://doi.org/10.1051/matecconf/201819305032 (2018)

11. Oleinik P., Yurgaytis A. The method of forming solutions for non-critical activities in the preparation and optimization of the construction complex organizations' annual program, MATEC Web of Conferences 193, $05010 \quad$ (2018), ESCI 2018, https://doi.org/10.1051/matecconf/201819305010

12. M. Rogalska, W. Bozejko, Z. Hejducki. Time/cost optimization using hybrid evolutionary algorithm in construction project scheduling, Automation in Construction (2008)

13. Bozejko, W., Hejducki, Z., Uchroński, M., Wodecki, M. Solving resource-constrained construction scheduling problems with overlaps by metaheuristic. Journal of Civil Engineering and Management (2014) 